\title{
UTILIZATION OF ORGANIC WASTE TO ORGANIC FERTILIZER IN THE ELEMENTARY SCHOOLS OF SIJUNJUNG DISTRICT
}

\author{
Faisal $^{1 *}$, Diky Setya Diningrat ${ }^{2}$, Batumahadi Siregar ${ }^{3}$, Kustoro Budiarta ${ }^{4}$ \\ ${ }^{1}$ Department of Primary School Teacher Education, Universitas Negeri Medan, Medan, Indonesia \\ ${ }^{2}$ Department of Biology, Universitas Negeri Medan, Medan, Indonesia \\ ${ }^{3}$ Department of Mechanical Engineering Education, Universitas Negeri Medan, Medan, Indonesia \\ ${ }^{4}$ Department of Management, Universitas Negeri Medan, Medan, Indonesia \\ *Corresponding Author: faisalpendas@gmail.com
}

\begin{abstract}
The Program for Applying Appropriate Technology (PPTTG) aims to utilize organic waste into organic fertilizer in SD Negeri 13 Muaro and SD Negeri 3 Muaro, Sijunjung District, Sijunjung Regency, West Sumatra Province. This program is carried out based on an analysis of problems faced by partners, including: (1) awareness of school residents disposing of rubbish where it is still low, (2) the amount of organic waste generated every day so that it becomes a serious problem for schools, (3) schools have not been able to treating organic waste into high quality products. Seeing this problem, it is necessary to look for solutions in the form of: (1) mentoring waste management literacy, (2) socialization of the utilization of organic waste into organic fertilizer, and (3) assistance using organic waste to technologybased organic fertilizer. The results of the application of technology showed that the average success rate of the program reached $85,11 \%$ with the Good category. This means that the application of technology in the form of utilizing organic waste into organic fertilizer can be implemented well in elementary schools in Sijunjung Regency.
\end{abstract}

Keywords: Organic Waste; Organic Fertilizer; Elementary School.

\section{INTRODUCTION}

Trash cannot be separated from human activities and its presence is difficult to avoid. In simple terms the term waste is a solid that is no longer used and discarded. Furthermore, it was also explained that waste is the remnant of human daily activities and/or solid natural processes (Undang-Undang Republik Indonesia Nomor 18 Tahun 2008 tentang Pengelolaan Sampah). The omission of waste that tends to increase from day to day often creates new problems in the form of landfill that has an impact on health.

Based on the material content, waste is grouped into two types, namely organic waste (waste originating from animal, plant and human parts) and inorganic waste (waste derived from mineral materials such as metal, glass, plastic, etc.) (Wahyono, 2011). Organic waste can be recycled into organic fertilizer because it contains organic material. Organic matter in fertilizer plays an important role in improving the physical, chemical, and biological properties of the soil so that it can maintain and increase soil fertility, as well as reduce dependence on inorganic/chemical fertilizers (Sulistyawati \& Nugraha, 2007).

Efforts to process organic material into organic fertilizer can be done by composting. Composting is a biological process carried out by microorganisms to convert organic solid waste into stable products that resemble humus (Wahyono, 2011). Composting is considered a sustainable technology because it aims to conserve the environment, human safety, and provide economic value. The use of compost helps to conserve the environment by reducing the use of chemical fertilizers that can cause land degradation. Indirect composting also helps human safety by preventing disposal of organic waste.

Compost as a result of composting and is one of the organic fertilizers that has an important function, especially in agriculture, among others: organic fertilizer contains macro and micro nutrients. Organic fertilizer can improve soil structure. Increasing the soil's absorption of water and nutrients, increasing the bonding capacity of sandy soils. Improve drainage and air conditioning in the soil. Helps the weathering process in the soil. Plants that use organic fertilizer are more resistant to disease (Cahaya \& Nugroho, 2009).

Based on the explanation above, landfill requires proper handling based on the number of actors, types and activities. On-site handling or handling of waste at the source is a treatment of waste that still has economic value, which is carried out before the garbage reaches the disposal site. Waste management in place has a significant influence on 
waste management in the next stage. Handling activities include sorting, reuse and recycle aiming to reduce the amount of waste generation (Setiadi, 2015).

Even so, waste management policies still often follow conventional policies that are felt to be inappropriate in dealing with waste problems. The implementation of conventional waste management policies causes an increase in the number of facilities and infrastructure, especially landfills, which are increasingly difficult to obtain due to limited land (Subandriyo et, al., 2012).

The problems mentioned above are also experienced by education centers such as Elementary Schools (SD). Based on observations at SD Negeri 13 Muaro and SD Negeri 03 Muaro, Sijunjung District, Sijunjung Regency, West Sumatra Province, limited land as a final disposal site makes waste often uncontrollable, causing serious problems for the health and beauty of the school.

Waste management should be carried out based on the principle of responsibility, the principle of sustainability, the principle of benefits, the principle of justice, the principle of awareness, the principle of togetherness, the principle of safety, the principle of security, and the principle of economic value (Undang-Undang Republik Indonesia Nomor 18 Tahun 2008 tentang Pengelolaan Sampah).

The role of schools should ensure the implementation of good and environmentally sound waste management. Every school citizen has rights and obligations in managing waste. Every school citizen is required to reduce waste and handle it in an environmentally sound manner. Based on this idea, waste management in SD Negeri 13 Muaro and SD Negeri 03 Muaro have started to be developed but are still conventional and simple so that further assistance is needed.

Simply put, a description of the environmental conditions and existing waste management in Sijunjung District Primary School can be seen in Figure 1, Figure 2, and Figure 3 below.

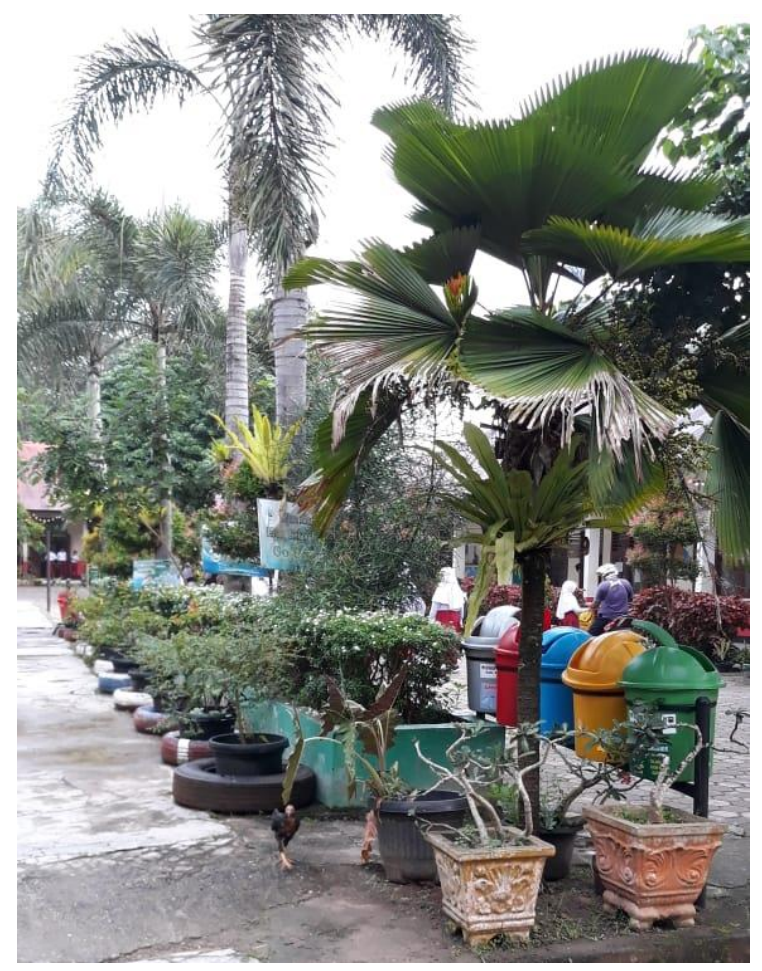

Figure 1. Environmental Conditions of SD Negeri 13 Muaro, Sijunjung District, Sijunjung Regency. 


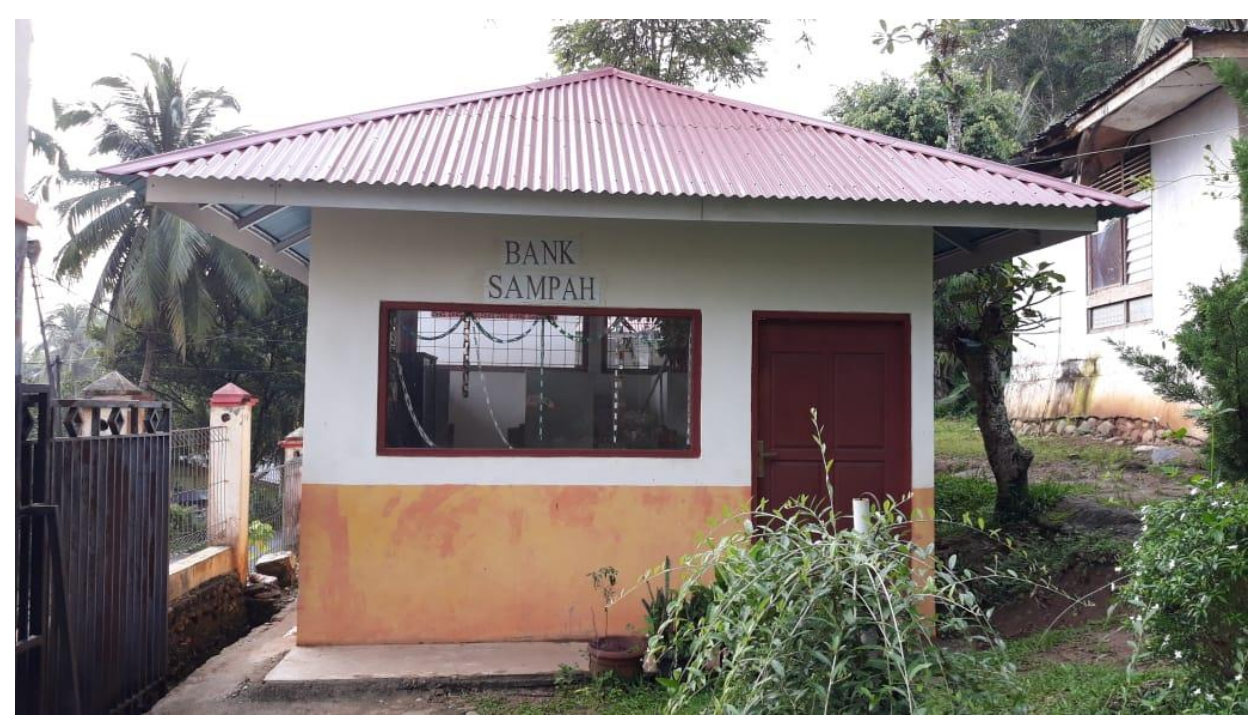

Figure 2. Garbage Bank of SD Negeri 13 Muaro, Sijunjung District, Sijunjung Regency.
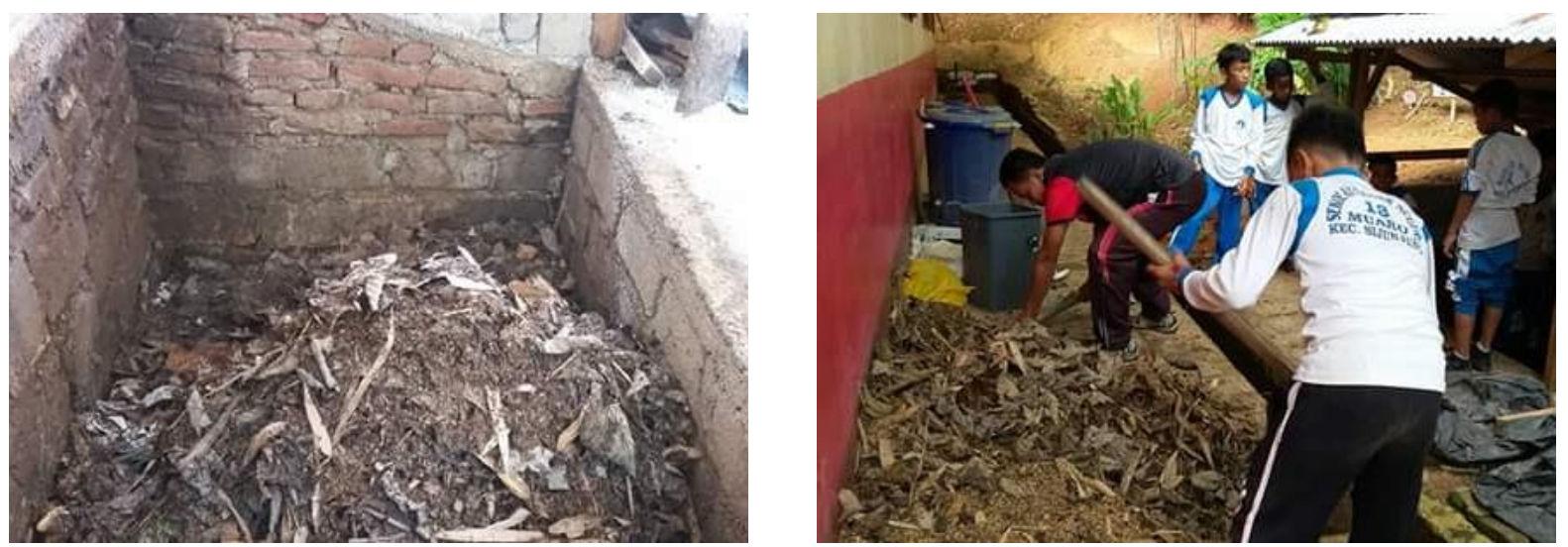

Figure 3. Waste Management in SD Negeri 13 Muaro, Sijunjung District, Sijunjung Regency.

Efforts to develop good waste management require detailed identification and characterization of waste. This stage provides a framework of the types of existing waste, the composition of waste, and the nature of waste. The characterization will help waste managers to find out who are the parties involved in the generation of waste, to predict the environmental impacts caused, and to align them with effective handling strategies (Arief, 2015).

Responding to the explanation above, mentoring has been carried out in SD Negeri 13 Muaro and SD Negeri 03 Muaro, Sijunjung District, Sijunjung District through the Application of Appropriate Technology Program for Utilizing Organic Waste into Organic Fertilizer. This program has helped schools in overcoming the problem of waste so it does not interfere with the learning process. Not only that, this program has helped develop the cleanliness and beauty of schools so that they can strengthen schools as one of the "Adiwiyata Schools" in Sijunjung Regency. 


\section{METHOD OF IMPLEMENTATION}

The methods and stages of applying technology can be seen in Figure 4 below.

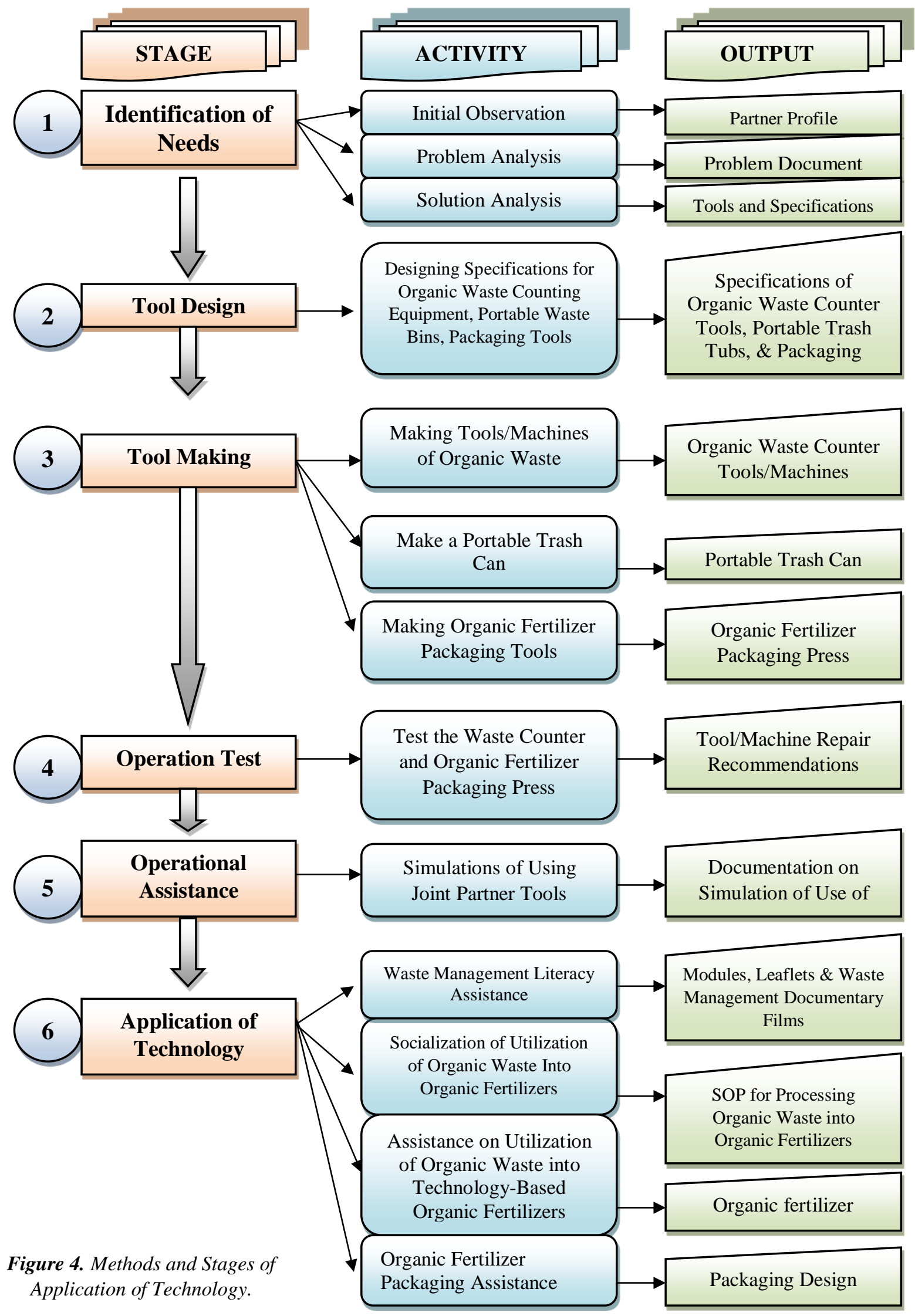


The information contained in Figure 4 can be explained in more detail as follows:

a. School Needs Identification

This stage is an analysis phase of partner needs, namely SD Negeri 13 Muaro and SD Negeri 3 Muaro. In this case, the partner's need is processing organic waste into organic fertilizer so that it can overcome the problem of garbage in the elementary school and the results can be utilized to maintain the fertility and beauty of the school environment. Not only that, waste processing that has been done manually and simply, needs to be improved in the form of technology-based processing. Furthermore, limited school land requires the provision of practical reservoirs and does not require land. Thus, the garbage collection bin does not have to be in the form of a permanent building, but can be made in the form of a portable tub.

\section{b. Design}

Based on the needs analysis, designed the technology needed to overcome the problems of partners. In designing tools, an analysis of product specifications will be carried out, starting from the design, capacity, and working principle of the tool. In this case, the items designed are the specifications of organic waste counting tools, specifications of portable waste bins, and specifications of organic fertilizer packaging tools. The person who formulates the specifications of the tool/technology in the design is a team of proposals who are experts in machinery.

\section{c. Manufacture}

After the design of tools is drawn from the specifications of the goods/tools to be used, the next step is to make the tools according to the initial design/specifications specified. In this case, the technology to be made is an organic waste counter, a portable waste bin, and a packaging design tool.

\section{d. Operation Test}

After making the tools/technology needed, a product feasibility trial is conducted. This means that limited trials are conducted to test the readiness and success of the tools that will be used during the mentoring process. This method is carried out to measure the effectiveness of the product and avoid operation failure when accompanied. For example, does the organic waste chopper function perfectly or not and is useful for measuring the success rate.

\section{e. Operational Assistance}

After the operation test is carried out, a simulation of the use of the tool with partners is conducted. Partners will be accompanied by how to use the equipment before actual assistance. Thus, partners will get initial experience on how to use tools and processing organic waste into organic fertilizer using the tools designed.

\section{f. Application of Technology to the Community}

After conducting the initial simulation of the use of the equipment, the technology will be applied to the community in the form of workshops and mentoring. The activities that will be carried out are the utilization of organic waste into organic fertilizer which is oriented to 4 main activities: (1) Facilitation of waste management literacy, (2) socialization of utilization of organic waste into organic fertilizer, (3) assistance of utilization of organic waste into technologybased organic fertilizer.

\section{RESULTS AND DISCUSSION}

\subsection{Activity Results}

The results of the Appropriate Technology Application Program (PPTTG) that have been carried out are grouped into 3 main parts, namely: (1) mentoring waste management literacy, (2) socialization of the utilization of organic waste into organic fertilizer, and (3) mentoring the utilization of organic waste into organic fertilizer technology based. For more details, it can be described as follows.

1. Waste Management Literacy Assistance

The implementation of the literacy program is a national program, so it needs to be implemented early, as included in education at the elementary school level (SD), and continued to the junior high school level (SMP). Its existence is an integral part of education to improve the quality of learning in schools. Therefore, the development of school literacy programs needs to get special attention so that it can be optimized by all school members (Harahap et. al., 2017).

Based on the program that has been implemented, the results of waste management literacy assistance activities can be seen in the following Table 1.

Table 1. Results Of Waste Management Literacy Assistance.

\begin{tabular}{|c|c|c|}
\hline No & Aspects Observed & Percentage (\%) \\
\hline 1 & Understanding Waste Management Literacy & 83,33 \\
\hline 2 & Waste Management Literacy Skills & 87,56 \\
\hline \multicolumn{2}{|c|}{ Average } & $\mathbf{8 5 , 4 4}$ \\
\hline Category & Good \\
\hline
\end{tabular}


Based on the data in Table 1, it can be explained that: (1) the percentage of participants' understanding of waste management literacy is at $83,33 \%$ with the Good category and (2) the percentage of successful waste management literacy skills by the participants is at $87,56 \%$ with the Good category. The average results of waste management literacy assistance are at $85,44 \%$ with the Good category. This means that waste management literacy assistance activities are well implemented in SD Negeri 13 Muaro and SD Negeri 03 Muaro, Sijunjung District, Sijunjung Regency, West Sumatra Province.

Simply, a picture of the results of literacy management assistance activities can be seen in Figure 5 below.

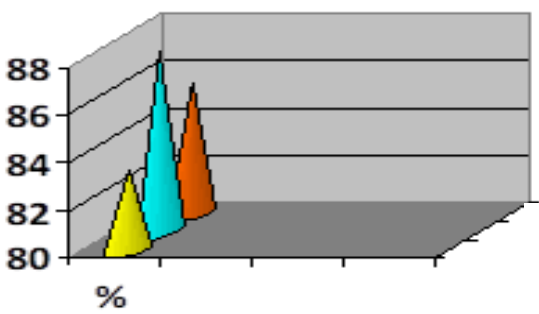

$\square$ Understanding
$\square$ The skills
$\square$ Average

Figure 5. Results of Waste Management Literacy Assistance.

\section{Socialization of Utilization of Organic Waste Into Organic Fertilizers}

The results of the socialization of the utilization of organic waste into organic fertilizer in SD Negeri 13 Muaro and SD Negeri 03 Muaro, Sijunjung District, Sijunjung Regency can be seen in Table 2 below.

Table 2. Results Of The Socialization Of Utilization Of Organic Waste Into Organic Fertilizers.

\begin{tabular}{|c|l|c|}
\hline No & \multicolumn{1}{|c|}{ Aspects Observed } & Percentage (\%) \\
\hline 1 & $\begin{array}{l}\text { Understanding of Utilization of Organic Waste into Organic } \\
\text { Fertilizers }\end{array}$ & 85,75 \\
\hline 2 & Skill of Utilizing Organic Waste into Organic Fertilizer & 84,37 \\
\hline \multicolumn{2}{|c|}{ Average } & $\mathbf{8 5 , 0 6}$ \\
\hline Category & Good \\
\hline
\end{tabular}

Based on the data in Table 2 it can be explained that: (1) the percentage of participants' understanding of the use of organic waste into organic fertilizer is at $85,75 \%$ with the Good category and (2) the percentage of practices of utilizing organic waste into organic fertilizer is at $84,37 \%$ with the Good category. The average success rate of the socialization of utilization of organic waste into organic fertilizer is at $85,06 \%$ with the Good category. That is, the socialization of the utilization of organic waste into organic fertilizer went well as expected.

Simply put, a description of the success rate of the socialization program of utilizing organic waste into organic fertilizer can be seen in Figure 6 below. 


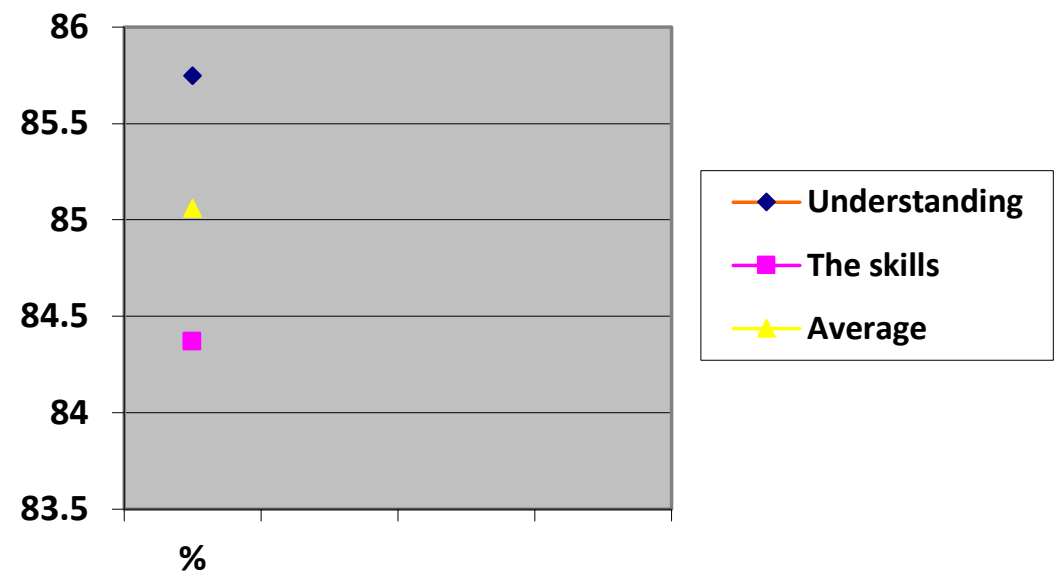

Figure 6. Results of the Socialization of Utilization of Organic Waste into Organic Fertilizers.

3. Assistance on Utilization of Organic Waste into Technology-Based Organic Fertilizers

The results of the assistance activities of utilizing organic waste into technology-based organic fertilizer can be seen in the following Table 3.

Table 3. Results Of Assistance Activities In Utilizing Organic Waste Into Technology-Based Organic Fertilizers.

\begin{tabular}{|c|l|c|}
\hline No & \multicolumn{1}{|c|}{ Aspects Observed } & Percentage (\%) \\
\hline 1 & $\begin{array}{l}\text { Understanding of Utilization of Organic Waste into } \\
\text { Technology-Based Organic Fertilizers }\end{array}$ & 83,68 \\
\hline 2 & $\begin{array}{l}\text { Skill of Utilizing Organic Waste into Technology-Based } \\
\text { Organic Fertilizers }\end{array}$ & 83,35 \\
\hline 3 & $\begin{array}{l}\text { Commitment to Utilize Organic Waste Into Technology- } \\
\text { Based Organic Fertilizers }\end{array}$ & 87,46 \\
\hline \multicolumn{2}{|c|}{ Average } & $\mathbf{8 4 , 8 3}$ \\
\hline Category & Baik \\
\hline
\end{tabular}

Referring to the data in Table 3, it can be explained that: (1) the percentage of participants' understanding of the use of organic waste into technology-based organic fertilizer is at $83,68 \%$ with the Good category, (2) the percentage of participant skills in utilizing organic waste to technology-based organic fertilizer is at $83,35 \%$ with the Good category, (3) the percentage of participants' commitment in utilizing organic waste into technology-based organic fertilizer was at $87.46 \%$ with the Good category. The average success rate of the assistance program for the utilization of organic waste into technology-based organic fertilizer is at $84,83 \%$ with the Good category. This means that the assistance activities of utilizing organic waste into technology-based organic fertilizer can be carried out well in SD Negeri 13 Muaro and SD Negeri 03 Muaro, Sijunjung District, Sijunjung Regency.

A simple description of activities to assist the utilization of organic waste into technology-based organic fertilizer in Sijunjung Regency can be seen in Figure 7 below.
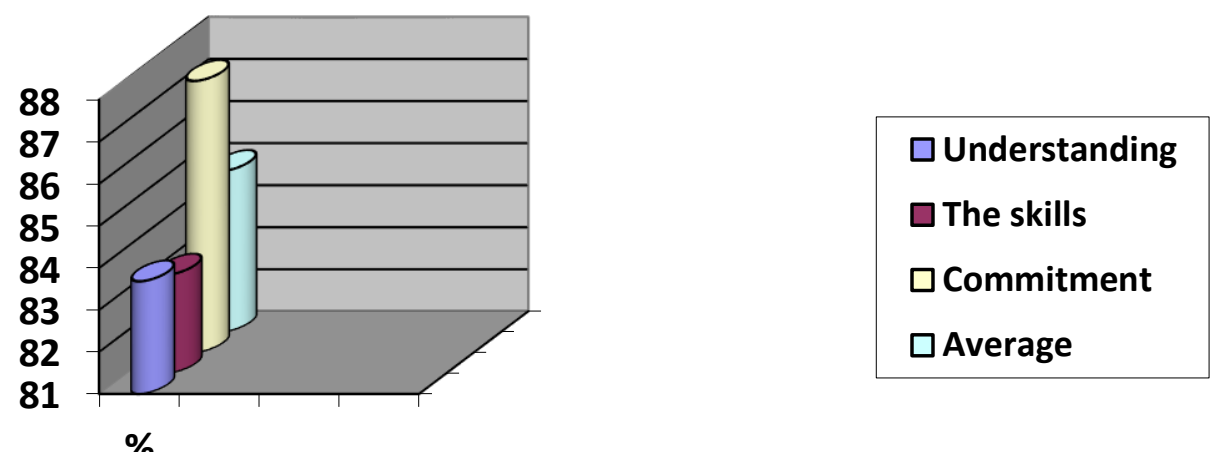

$\%$

Figure 7. Results of Assistance in Utilizing Organic Waste into Technology-Based Organic Fertilizers. 


\subsection{Discussion}

The effectiveness of a program is characterized by the following characteristics: (a) successfully leads participants to achieve instructional goals that have been set, (b) provides an attractive learning experience, actively involves participants so as to support the achievement of instructional goals, (c) has facilities that support the activity process (Faisal, 2018). Furthermore, it was also explained that the success of the program was marked by a percentage of success of at least $\geq 75 \%$ in the good category (Nasrun et, al., 2018). Based on this explanation, the results of the activities of Utilizing Organic Waste Into Organic Fertilizers in Sijunjung District Elementary School can be described as follows.

1. Waste Management Literacy Assistance

The average results of waste management literacy assistance are at $85,44 \%$ with the Good category. If referring to the opinions of Firman \& Nasrun, et all. it can be concluded that the waste management literacy assistance activities have been successfully carried out with good categories. This means that participants have a good understanding and skills in waste management literacy in Sijunjung District Elementary School.

\section{Socialization of Utilization of Organic Waste Into Organic Fertilizers}

The average success rate of the socialization of utilization of organic waste into organic fertilizer is at $85 \%$ with the Good category. Referring to the opinion of Firman \& Nasrun, et all. it can be seen that the socialization activities of utilizing organic waste into organic fertilizer run well as expected. This means that participants have good understanding and skills in utilizing organic waste into organic fertilizer in Sijunjung District Elementary School.

\section{Assistance on Utilization of Organic Waste into Technology-Based Organic Fertilizers}

The average success rate of the assistance program for the utilization of organic waste into technology-based organic fertilizer is at $84,83 \%$ with the Good category. Referring to the opinion of Firman \& Nasrun, et all. it can be concluded that the activities of assisting the utilization of organic waste into technology-based organic fertilizer have been able to be carried out well in SD Negeri 13 Muaro and SD Negeri 03 Muaro, Sijunjung District, Sijunjung Regency.

\section{CONCLUSION}

Based on the activities that have been carried out, a number of conclusions have been obtained, including: (1) Waste management literacy assistance activities have been successfully carried out with good categories. This means that participants have a good understanding and skills in waste management literacy in Sijunjung District Elementary School. (2) The socialization of the utilization of organic waste into organic fertilizer runs well as expected. This means that participants have good understanding and skills in utilizing organic waste into organic fertilizer in Sijunjung District Elementary School. (3) assistance in the utilization of organic waste into technology-based organic fertilizer has been carried out well in SD Negeri 13 Muaro and SD Negeri 03 Muaro, Sijunjung District, Sijunjung Regency.

\section{ACKNOWLEDGEMENT}

The author would like to thank the DRPM Kemenristekdikti and LPPM Universitas Negeri Medan for being willing to fund and facilitate the implementation of the Appropriate Technology Application Program in Elementary Schools of Sijunjung Regency. Furthermore, thanks are also extended to the Department of Education and Elementary Schools in Sijunjung Regency, who have been willing as collaborator partners so that the community service program can be implemented well.

\section{REFERENCES}

Arief, S. (2015). Pengelolaan Sampah Malang Raya Menuju Pengelolaan Sampah Terpadu yang Berbasis Partisipasi Masyarakat. Jurnal Humanity, 9 (1).

Cahaya, T. S., \& Adi Nugroho, D. (2009). Pembuatan Kompos dengan Menggunakan Limbah Padat Organik (Sampah Sayuran dan Ampas Tebu).

Faisal, F. (2018). Persepsi Mahasiswa PGSD terhadap Implementasi KKNI di Universitas Negeri Medan. Jurnal Inovasi Pendidikan dan Pembelajaran Sekolah Dasar, 2(1).

Harahap, M. H., Faisal, F., Hasibuan, N. I., Nugrahaningsih, R. H. D., \& Azis, A. C. K. (2017). Pengembangan Program Literasi Sekolah untuk Meningkatkan Kualitas Pendidikan Dasar Tingkat Sekolah Menengah Pertama Negeri di Kota Medan. Jurnal Pembangunan Perkotaan, 5 (2), 115-128.

Nasrun, N., Faisal, F., \& Feriyansyah, F. (2018). Pendampingan Model Pembelajaran Inovatif di Sekolah Dasar Kecamatan Medan Selayang Kota Medan. Jurnal pengabdian kepada masyarakat, 24(2), 671-676.

Setiadi, A. (2015). Studi Pengelolaan Sampah Berbasis Komunitas pada Kawasan Permukiman Perkotaan di Yogyakarta. Jurnal Wilayah dan Lingkungan, 3 (1), 27-38.

Subandriyo, S., Anggoro, D. D., \& Hadiyanto, H. (2012). Optimasi Pengomposan Sampah Organik Rumah Tangga Menggunakan Kombinasi Aktivator EM4 dan Mol Terhadap Rasio C/N. Jurnal Ilmu Lingkungan, 10 (2), 7075 . 
Sulistyawati, E., \& Nugraha, R. (2007). Efektivitas Kompos Sampah Perkotaan sebagai Pupuk Organik dalam Meningkatkan Produktivitas dan Menurunkan Biaya Produksi Budidaya Padi. Sekolah Ilmu dan Teknologi Hayati-ITB. Bandung.

Undang-Undang Republik Indonesia Nomor 18 Tahun 2008 tentang Pengelolaan Sampah.

Wahyono, S. (2011). Pengolahan Sampah Organik dan Aspek Sanitasi. Jurnal Teknologi Lingkungan, 2 (2). 